\title{
Norwegian masse: from measure noun to quantifier
}

\author{
Torodd Kinn
}

\begin{abstract}
For a little more than a century, a new quantifier has been developing in Norwegian: masse 'a lot, lots, many, much'. The article compares the quantifier to its source noun masse 'matter, mass, large amount'. The historical development is studied based on several corpora. The development of a new quantifier is seen in the larger picture of the variability of measure noun constructions and the tendency for certain kinds of measure nouns to grammaticalize into quantifiers.
\end{abstract}

\section{Introduction}

In spoken and informal written Norwegian, a new quantifier has been developing for a few generations, apparently since the decades around 1900. The newcomer masse 'a lot, lots, many, much' is advancing into the territory of the older quantifiers mange 'many' and mye 'much'. Examples (1) and (2) show its use with a count and a noncount noun, respectively, while (3) illustrates that it can also be used as a quantifying adverbial: ${ }^{1}$

(1) Jeg hadde drukket masse halvlitere
I had drunk a.lot pints

'I'd drunk lots of pints'

(2) Alle bruker masse tid på ̊̊ bevise at Gud fins

all use a.lot time on to prove that God exists

'Everybody spends lots of time proving that God exists'

(3) Terry snakker masse om deg

Terry talks a.lot about you

'Terry talks a lot about you'

1 Sources of examples are provided after the main text. In the interlinear glosses, I use a.lot to translate the quantifier masse 'a lot, lots, many, much' and lot to translate the noun masse when it means '(a) lot', alternatively mass when appropriate. Morphological abbreviations are kept to a minimum; the following are used when relevant: $\mathrm{ABU}=$ plural of abundance; $\mathrm{C}=$ common gender; $\mathrm{M}=$ masculine; $\mathrm{N}=$ neuter; $\mathrm{PL}=$ plural; $\mathrm{PST}=$ past tense; $\mathrm{SG}=$ singular; $\mathrm{REFL}=$ reflexive . 
The origin of the quantifier masse is well known and quite transparent; it is the indefinite singular of the masculine noun masse 'matter, mass, large amount' used as a measure noun with the meaning 'large amount' (see Section 2). The use of this measure noun is illustrated with examples (4)-(6) parallel to (1)-(3):

(4) Jeg har truffet en masse mennesker

I have met a.M $\operatorname{lot}(\mathrm{M})$ human.beings

'I've met lots of people'

(5) Det kan $i$ hvert fall forårsake en masse hat

it can in every case cause a.M $\operatorname{lot}(\mathrm{M})$ hatred

'At any rate, it can cause lots of hatred'

(6) De hadde spurt en masse og glodd nysgjerrig på ham they had asked a.m $\operatorname{lot}(\mathrm{M})$ and stared curiously on him

'They'd asked about lots of things and stared curiously at him'

Here, the only apparent difference between the quantifier and the noun is the use of the agreeing indefinite article en 'a'. But we will see that there are other differences as well, which firmly establish the status of bare masse as a quantifier rather than a noun.

This article investigates the development of the new quantifier from a noun: How and when did it happen, and what is the reason for it? The analysis offered builds crucially on the semantics of the constructions involved, since the observed development needs to be understood as reanalysis that overrides overt morphosyntax.

Below, I will mostly write masse $_{Q}$ for the quantifier, masse $M N$ for the noun in its measure-noun use/meaning, and masse $_{N}$ for the noun when it is not a measure noun (see Section 2) or when it is not essential to differentiate between measure noun and non-measure noun.

\section{Preliminaries}

When an expression like masse develops historically from a noun into a quantifier, it crosses a major semantic divide: Whereas nouns designate conceptual things ${ }^{2}$ (nominal entities), quantifiers designate conceptual relationships (relational entities). The change involves a significant semantic and syntactic restructuring.

The things designated by nouns are of three fundamental types: individuals (singular count nouns), count masses (plural count nouns), and noncount masses (noncount nouns). Many quantifiers combine with either plural count nouns or noncount nouns and specify the quantity of the count or noncount masses as wholes. Quantifiers meaning 'one', 'every' and some others combine only with singular count nouns. Quantifiers are in many ways similar to adjectives. But the latter combine freely with

2 Thing is a term in the conceptual semantics of Cognitive Grammar. 
all three types of nouns and specify some quality of individuals (as designated by singular count nouns or as members of the masses designated by plurals) or of arbitrary submasses of noncount masses. For instance, in three black cats, the quantifier specifies the cardinality of the count mass and the adjective specifies the colour of the members of that mass. And in much black coffee, the quantifier specifies loosely the volume of the noncount mass and the adjective specifies the colour of (the mass and) any given submass.

Measure nouns are a subclass of nouns. They are identified on the basis of their participation in measure noun constructions, also known as pseudopartitives (e.g. Kinn 2001) and under various other terms (cf. Brems 2011, p. 19-26), e.g. (7)-(8).

(7) en mengde bøker

a.m $\operatorname{lot}(\mathrm{M})$ books

'a lot of books'

(8) noen glass med øl

some.PL glasses with beer

'some glasses of beer'

These are binominal constructions, with a substance noun providing a mostly qualitative categorization of a referent and a measure noun contributing mostly quantitative information about the same referent - plus possibly some case or prepositional marking connecting the nouns (see below). In this article, I will speak about measure nominals and substance nominals as separate parts of measure noun constructions, although one of them will always be part of the other, depending on which noun heads the construction.

Faarlund et al. (1997, p. 238) make a useful distinction between secondary and primary measure nouns: Secondary measure nouns have a relatively clear qualitative meaning in addition to that of quantity, indicating shape (e.g. English slice, drop), configuration (pile, herd), or containment (glass, barrel). Primary measure nouns have more or less exclusively quantitative meaning: specific number (million, dozen), indefinite number (e.g. number in a number of books), conventional measures (mile, litre, ton), indefinite quantity (e.g. amount in a large amount of sugar). Some measure nouns are restricted to constructions where the substance noun is countable, while others are not. Norwegian masse $_{M N}$ is a primary measure noun of indefinite (large) quantity without any restrictions on the countability of the substance nominal, as shown above by (4) and (5).

Norwegian count nouns regularly exhibit paradigms with four inflectional forms (singular vs. plural and indefinite vs. definite). But measure nouns capable of referring to large quantities are also characterized by the formation of an additional inflectional 
form, the abundance plural (Enger and Conzett 2016; Kinn 2004, 2005). Thus, Norwegian Bokmål masse $_{M N}$ has the forms masse (sg. indef.), massen (sg. def.), masser (pl. indef.), massene (pl. def.), massevis (abundance plural).

As illustrated in examples (4) and (5) above, the measure noun and the substance noun in Norwegian measure noun constructions are often juxtaposed, with no marking of one noun being subordinate to the other. This is different from English, where most measure noun constructions involve the use of the preposition of (e.g. two pounds of sugar, lots of people). ${ }^{3}$ Koptjevskaja-Tamm (2001) shows that European languages commonly exhibit three kinds of marking in measure noun constructions: zero (juxtaposition), prepositional marking of the substance nominal (as in English), and case marking of the substance nominal (e.g. most Slavic languages). In some languages, two or more patterns exist alongside one another, partly in competition. This is the case in Norwegian, where besides juxtaposition there are constructions involving the prepositions med 'with' and $a v$ 'of' (Kinn 2001). There is much variation, depending mostly on properties of the measure nominal: noun meaning, inflectional form, and modification (see further Section 3 for the case of masse $_{M N}$ ).

\section{The measure noun masse}

Derived from a verb meaning 'knead', the Ancient Greek noun mâza 'barley-bread, cake' was borrowed into Latin as massa 'lump, dough, bulk (of material)'. This word is found in various forms in European languages, including Spanish (masa), French (masse), English (mass), and German (Masse), in Swedish and Dutch (massa) and in Danish and Norwegian (masse). Into Danish, which was the written language of Norway for several centuries, it was borrowed as Massa, a form that was gradually replaced by Masse, cf. (9) and (10):

(9) Det er en Gift af en ubekiendt Natur, som omløber i it is a poison of an unknown nature which runs.around in Blodets Massa

the.blood's mass

'It is a poison of an unknown nature which circulates in the blood mass'

(10) I en saa uhyre Sal med en saadan Masse Mennesker er
in a so immense hall with a.c such.c mass(c) human.beings is det ligemeget ...

it as.much ...

'In such an immense hall with such a lot of people, it does not matter ...'

According to the modern dictionary Bokmålsordboka (Bokmålsordboka 2005, s.v. masse), masse $_{N}$ now has four main meaning variants: (1) '(shapeless) matter, sub-

3 Numeral nouns are partly exceptions to this, e.g. two million people, but millions of people. 
stance', (2) 'mass' (the physics notion), (3) 'large amount', and (4) 'most people, the masses' (when used in the definite plural). ${ }^{4}$ The first and second variants are illustrated in (11)-(12):

$\begin{array}{lllll}\text { en skvulpende, } & \text { seig } & \text { masse } & \text { som kalles flytende metallisk } \\ \text { a.M sloshing } & \text { viscous.m } & \operatorname{matter}(\mathrm{M}) & \text { that is.called floating metallic } \\ \text { hydrogen } & & & & \end{array}$

hydrogen

'a sloshing, viscous matter called liquid metallic hydrogen'

(12) Bruk grafen til a bestemme solas masse
use the.graph to to decide the.Sun's mass
'Use the graph to decide the mass of the Sun'

The third variant mentioned in Bokmålsordboka ('large amount') may be classified as a measure noun, and it is from this that masse $_{Q}$ has developed. The noun is frequent as the head of compounds, e.g. muskelmasse 'muscle mass', kokosmasse 'shredded coconut', fugemasse 'grout' (lit. 'joint mass'), folkemasse 'crowd of people'.

As noted above, Norwegian measure noun constructions may be juxtapositional or employ either of the prepositions med 'with' and $a v$ 'of'. Since masse $e_{Q}$ has developed from indefinite singular en masse, the use of juxtaposition or a preposition after the indefinite singular masse $_{M N}$ is more central here than that seen with other forms of masse $_{M N}$. Indefinite singular en masse (without further modification, or modified by an intensifying adjectival expression, typically hel 'whole' or helvetes 'helluva') is usually used in juxtaposition, illustrated in (4)-(5). The preposition med is sometimes used, as in (13), while the use of $a v$ is mostly restricted to contexts with other meanings of masse $_{N}$. But when masse $_{M N}$ is (uncharacteristically) modified by a dimensional adjective, $a v$ still tends to be used, as in (14); the borderline between measure noun and other uses is here often quite fuzzy.

(13) Dette kommer selvfølgelig til å koste en masse med penger this comes of.course to to cost a.M $\operatorname{lot}(\mathrm{M})$ with money.PL

'This is going to cost lots of money, of course'

(14) [De] oppleves som ... problematiske for en stor masse av they are.experienced as ... problematic for а.м large.m $\operatorname{lot}(\mathrm{M})$ of samtidige lesere contemporary readers

'They are felt as problematic for a large number of contemporary readers'

4 Variant (4) might better be regarded as a version of variant (3), but will not be discussed further here. 
Turning to the external agreement properties of measure noun constructions with masse $_{M N}$, it should be noted that it is the substance noun rather than masse ${ }_{M N}$ that determines agreement on adjectival predicate complements and predicate adjuncts. Two examples are provided in (15)-(16), where the adjectives (verdiløse and kunnskapsmette) agree with the substance nouns (penger and studiner, respectively). Agreement with masse $_{M N}$ (verdiløs, kunnskapsmett) would, in my judgement, be ungrammatical.

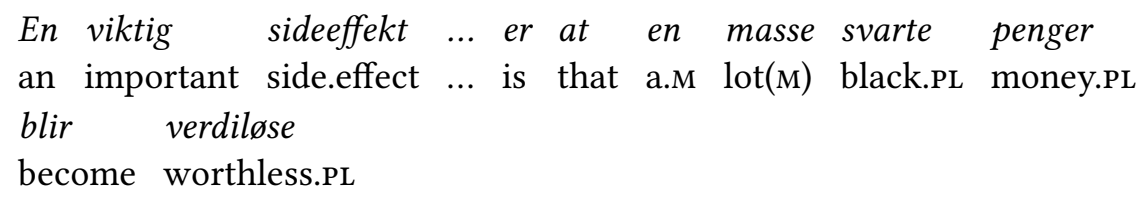

'An important side effect is that lots of black money becomes worthless'
(16) En masse yndige studiner veltet kunnskapsmette ... inn a.m $\operatorname{lot}(\mathrm{M})$ graceful.PL female.students crowded knowledge.full.PL $\ldots$ in på bussen on the.bus

'Lots of graceful female students crowded into the bus, their heads packed with knowledge.'

Note that even if one inserts the preposition med, the adjective agrees with the substance noun; it is hard to find authentic examples, though. Using the preposition av does not seem natural in these examples.

\section{The quantifier masse}

In order to find early instances of masse $_{Q}$, I have searched in the collections of the National Library of Norway. ${ }^{5}$ I may have overlooked examples, but the oldest case of masse $_{Q}$ that I have found is from a book translated from English, published in 1886. The quantifier is capitalized in agreement with its nominal origin and the orthography of 19 th century Danish. The example is given in (17).
(17) Træstammen ... stod midt i Masse af halvraadne Stubber the.tree.trunk ... stood in.the.middle in a.lot of half.rotten stumps og Rødder
and roots

'The tree trunk stood among lots of half rotten stumps and roots'

It may be noted that the quantifier is followed by the preposition af (modern Norwegian $a v$ ) 'of', which sounds slightly strange in (modern) Norwegian but is apparently the normal use of masse $_{Q}$ in modern Danish (see below). In the next example that I

5 http://www.nb.no/ 
have found (also in a book translated from English) from 1907, masse $Q$ is followed by med 'with', see (18); this sounds acceptable in modern Norwegian, too.

(18) Nei tak, maa jeg be om noget lyst og livligt og no thank may I pray about something bright and lively and masse med sol! a.lot with sun

'No thanks, may I ask for something bright and lively and lots of sun!'

Example (19) is from a book published in 1913, containing students' songs from the period 1813-1913. The book does not tell the age of this particular song, but it refers to a "children's help day", a phenomenon occurring first in Kristiania (now Oslo) in 1906, which narrows the range of possible periods for the expression to 1906-13.

(19) Saa næste gang de masse smaa skal hjælpes, vil jeg so next time the.PL a.lot small.pL shall be.helped will I passe paa at faa en tiggerbøsse selv at drasse paa make.sure on to get a beggar.box self to haul on 'So the next time the many small ones are going to be helped, I will make sure to have a beggar's box to haul around myself'

Here, masse $_{Q}$ is used in a definite noun phrase, a usage that appears to have gone extinct; at least, this is the only instance I have found of it, and it sounds strange to the modern speaker.

The oldest example that I have found of the typical use of masse $_{Q}$ - in indefinite noun phrases without a following preposition - is from 1914 and used in a Norwegian novel, see (20). The next two, (21)-(22), are from translations from English and Swedish and published in 1916 and 1919, respectively.

(20) og Hans kommer hjem med masse skiddent tøi and Hans comes home with a.lot dirty laundry 'and Hans comes home with lots of dirty laundry'

(21) posten kom; med masse kort, pakker og brever the.post came with a.lot cards packets and letters 'the post arrived, with lots of cards, packets and letters'

(22) den lignet mest en liten dverg med masse rynker og stort, it resembled most a little dwarf with a.lot wrinkles and large sort skjeg

black beard

'it resembled most (of all) a little dwarf with lots of wrinkles and a large, black beard' 
It would seem that the use of masse as a quantifier started to become conventionalized around 1900. Provided that the example from 1886 is not just a misprint, the development towards a quantifier had already started by then, and it is hard to estimate exactly when it began.

Norsk riksmålsordbok (1937-1957, vol. 2, part 1, s.v. masse I), whose first issues were edited before World War II, states that masse $_{M N}$ (rather than the other meanings of masse $_{N}$ ) belongs to "familial" language. Further, it is noted that it may be used "uten ubest[emt] artikkel, følt som adj[ektiv]" - "without the definite article, felt to be an adjective' (recall the semantic resemblance between adjectives and quantifiers, modifying different aspects of nominal meaning). One example of such usage is given in (23).

(23) han har hatt masse penger

he has had a.lot money.PL

'he must have had lots of money'

In Norsk referansegrammatikk (Faarlund et al. 1997, p. 238) it is observed half a century later that masse may be used without the indefinite article en 'a', achieving "nærmest ren kvantorstatus" - 'almost a pure quantifier status'.

It may be noted that the development of masse $_{M N}$ into a quantifier is not an isolated Norwegian phenomenon, but is also found in Swedish and Danish. Swedish masse $Q$ is like Norwegian masse $_{Q}$ in normally being immediately followed by the substance noun, while Danish masse $_{Q}$ tends to be followed by af 'of', cf. (24) and (25), respectively. ${ }^{6}$

(24) Kände hur massa stearin rann på ryggen när jag sjöng felt how a.lot stearin ran on the.back when I sang

'(I) felt how lots of candle wax was running down my back as I was singing'
Et velholdt feriehus
med masse af charme
a well.kept holiday.house with a.lot of charm
'A well kept holiday house with lots of charm'

See also Clerck and Brems (2015) for the grammaticalization of mass(es) of in English. Being a noun, masse $_{M N}$ is typically preceded by the agreeing indefinite article en and sometimes an agreeing adjective. Quantifiers, on the other hand, resemble adjectives semantically and may take degree modifiers if their semantics is suitable for that. Thus, while masse $_{M N}$ may be modified by the agreeing adjective enorm 'enormous' in (26), masse $_{Q}$ may be modified by the same adjective in the neuter singular form enormt 'enormous(ly)' as in (27); this form is the one that adjectives take when used adverbially.

6 I have not investigated the frequencies of these quantifiers. 
(26) de har en enorm masse nyttig informasjon they have a.M enormous.m $\operatorname{lot}(\mathrm{M})$ useful information 'They have an enormous amount of useful information'

(27) Lenken gir også tilgang til enormt masse info the.link gives also access to enormous.N a.lot information 'The link also gives access to an enormous amount of information'

In the oldest corpus that I have used (cf. Section 4), the demonstrative adjective saadan 'such' (modern: sainn) is used in front of masse $_{M N}$, as in (28), showing the nominal status of masse. Modern masse $_{Q}$ is preceded by the demonstrative adverb så 'so', as in (29), demonstrating the change from measure noun to quantifier:

(28) jeg skrev en saadan Masse Breve til ham og Broderen om I wrote a.m such.m $\operatorname{lot}(\mathrm{M})$ letters to him and the.brother about alverdens Smaating

all.the.world's little.things

'I wrote such a lot of letters to him and his brother about all kinds of little things'

(29) da så hun så masse rare ting then saw she so a.lot strange things 'then she saw so many strange things'

\section{A corpus study of masse as a measure noun and as a quan- tifier}

In order to look closer into the development of masse $_{Q}$ through time, I have used corpora of primarily fictional literature. The focus on such genres is motivated by the fact that masse $_{M N}$, and in particular masse $_{Q}$, are typical of informal language. To investigate the stylistic value of these words, the newest fiction corpus is compared with corpora from other genres: newspapers, journals (thematically specialized, but not necessarily academic), and laws and official reports. Laws and official reports are very formal genres where informal language is unlikely to be used, while thematic journals are intermediate in formality between laws and reports and fiction. Newspapers are mostly informal. The studied corpora are as follows:

- Tekstsamlingen 'The Text Collection' (TxtC), comprising primarily fiction, but also letters and other genres, mostly from the 19th century; ${ }^{7}$

- subcorpora of The Oslo Corpus of tagged Norwegian texts (Bokmål) (OsloK): novels from (a) 1937, (b) 1957, (c) 1977, and (d) laws and Official Norwegian Reports (NOUs) from the period $1981-95 ;^{8}$

7 www.dokpro.uio.no/litteratur

8 www.tekstlab.uio.no/norsk/bokmaal 
- subcorpora of The Lexicographic Corpus for Norwegian Bokmål (about 19852013) (LBK): (a) fictional literature, (b) national, regional, and local newspapers, and (c) journals. ${ }^{9}$

These corpora were searched for tokens of masse and Masse. The search in the lexicographic fiction corpus was limited to 500 randomly selected hits, while the other searches included all hits in the specified (sub)corpora. The hits were collected in a spreadsheet and categorized semantically and syntactically. First, the tokens were cat-

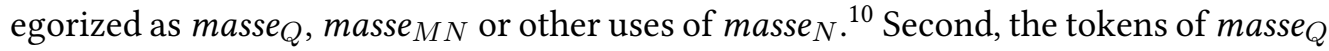
and masse $_{M N}$ were categorized according to the type of substance nominal: singular, plural or none (including adverbial uses and cases of an implicit substance nominal).

The quantitative results of the corpus studies are summarized in Tables 1 and 2 . While masse $_{M N}$ accounts for less than half the tokens in the oldest texts and masse $_{Q}$ is absent, together they amount to about $90 \%$ in all the later fictional corpora as well as modern newspapers. In modern laws and reports, there are very few cases; the other meanings of masse $_{N}$ dominate completely. The corpus of journals takes an intermediate position.

\begin{tabular}{|c|c|c|c|c|c|c|c|c|}
\hline & \multicolumn{2}{|c|}{ 19th c. } & \multicolumn{2}{|c|}{1937} & \multicolumn{2}{|c|}{1957} & \multicolumn{2}{|c|}{1977} \\
\hline & $\mathrm{N}$ & $\%$ & $\mathrm{~N}$ & $\%$ & $\mathrm{~N}$ & $\%$ & $\mathrm{~N}$ & $\%$ \\
\hline en (A) masse $_{M N}$ & 82 & 43.9 & 23 & 74.2 & 13 & 65.0 & 31 & 68.9 \\
\hline + sg. & 24 & 12.8 & 5 & 16.1 & 2 & 10.0 & 12 & 26.7 \\
\hline + pl. & 51 & 27.3 & 11 & 35.5 & 7 & 35.0 & 11 & 24.4 \\
\hline other & 7 & 3.7 & 7 & 22.6 & 4 & 20.0 & 8 & 17.8 \\
\hline masse $_{Q}$ & - & - & 5 & 16.1 & 5 & 25.0 & 9 & 20.0 \\
\hline+ sg. & - & - & 2 & 6.5 & 3 & 15.0 & 5 & 11.1 \\
\hline + pl. & - & - & 3 & 9.7 & 1 & 5.0 & 4 & 8.9 \\
\hline other & - & - & - & - & 1 & 5.0 & - & - \\
\hline 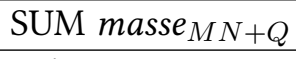 & 82 & 43.9 & 28 & 90.3 & 18 & 90.0 & 40 & 88.9 \\
\hline 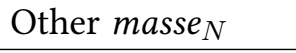 & 105 & 56.1 & 3 & 9.7 & 2 & 10.0 & 5 & 11.1 \\
\hline SUM total & 187 & 100.0 & 31 & 100.0 & 20 & 100.0 & 45 & 100.0 \\
\hline
\end{tabular}

Table 1: Masse in corpora of mostly fiction up to 1977. The labels $+\mathrm{sg}$. and + pl. refer to the number of the following substance nominal. There are no examples of prepositional measure noun constructions.

9 www.hf.uio.no/iln/tjenester/kunnskap/sprak/korpus/skriftsprakskorpus/lbk/

10 The 'rest' category includes cases of den (adjective) masse 'the (adjective) amount/mass', especially in 19th century texts. This use is not a precursor of masse $_{Q}$, which is used virtually exclusively in indefinite phrases. Further, it is particularly difficult to differentiate between measure and non-measure use of masse $_{N}$ in these cases. 
There are no examples of masse $_{Q}$ in the oldest texts, but it has a clear presence in 1937 fiction with about a sixth of the masse tokens, growing to more than half in the latest period of fiction (as well as journals) - and more than two thirds in modern newspapers. There is only one example in the modern laws and reports, i.e. less than $1 \%$. While there are more tokens of masse ${ }_{M N}$ than of masse $_{Q}$ up to 1977, the opposite holds in all the modern corpora except for laws and reports.

As noted above, masse $_{M N}$ is used with both count (plural) and noncount (singular) substance nominals, and masse $_{Q}$ continues this flexibility. However, there is a tendency towards differentiation in relative numbers. Masse $_{M N}$ clearly prefers plural substance nominals over singulars, and the tendency seems to have grown stronger over time, with plurals almost twice as frequent as singulars. Masse $_{Q}$ seems to have gone from a weak preference for plural substance nominals in 1937 fiction to a weak preference for singulars in the youngest texts - the difference between the singular and the plural is small, but remarkably similar across genres.

\begin{tabular}{|c|c|c|c|c|c|c|c|c|}
\hline & \multicolumn{2}{|c|}{ Fiction } & \multicolumn{2}{|c|}{ Newspapers } & \multicolumn{2}{|c|}{ Journals } & \multicolumn{2}{|c|}{ Laws/reports } \\
\hline & $\mathrm{N}$ & $\%$ & $\mathrm{~N}$ & $\%$ & $\mathrm{~N}$ & $\%$ & $\mathrm{~N}$ & $\%$ \\
\hline en (A) masse $_{M N}$ & 186 & 37.2 & 46 & 22.5 & 96 & 20.0 & 2 & 1.9 \\
\hline$+\mathrm{sg}$ & 55 & 11.0 & 12 & 5.9 & 24 & 5.0 & - & - \\
\hline+ pl. & 102 & 20.4 & *25 & 12.3 & $* * * 61$ & 12.7 & 2 & 1.9 \\
\hline other & 29 & 5.8 & 9 & 4.4 & 11 & 2.3 & - & - \\
\hline masse $_{Q}$ & 263 & 52.6 & 139 & 68.1 & 251 & 52.2 & 1 & 0.9 \\
\hline$+\mathrm{sg}$ & 119 & 23.8 & 67 & 32.4 & $* * * 113$ & 23.5 & - & - \\
\hline$+\mathrm{pl}$ & 107 & 21.4 & $* * 61$ & 29.9 & 105 & 21.8 & 1 & 0.9 \\
\hline other & 37 & 7.4 & 11 & 5.9 & 33 & 6.9 & - & - \\
\hline SUM masse $_{M N+Q}$ & 449 & 89.8 & 185 & 90.7 & 347 & 72.1 & 3 & 2.8 \\
\hline 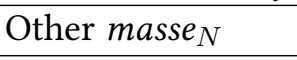 & 51 & 10.2 & 19 & 9.3 & 134 & 27.9 & 103 & 97.2 \\
\hline SUM total & 500 & 100.0 & 204 & 100.0 & 481 & 100.0 & 106 & 100.0 \\
\hline
\end{tabular}

Table 2: Masse in modern corpora of different genres. The labels $+\mathrm{sg}$. and + pl. refer to the number of the following substance nominal. *This number includes one prepositional example with med. ${ }^{* *}$ This number includes one prepositional example with $a v$ in clefting of the substance nominal, where this preposition is compulsory. ${ }^{* * *}$ Each of these numbers includes two prepositional examples with (noncompulsory) $a v$.

\section{The larger picture: the variability of measure noun construc- tions}

The modern Norwegian juxtapositional measure noun construction stems from an older construction with a genitive-marked substance nominal (e.g. Old Norse alin vaðmáls '(an) ell of frieze' with -s marking the genitive). Like the prepositional con- 
structions, this older construction appears to show that the substance nominal is subordinate to the measure noun. On the other hand: "The structure of juxtapositional pseudopartitives [...] has been what we may call a classic problem: Are such expressions headed by the measure noun or by the substance noun?" (Kinn 2001, p. 2; cf. Diderichsen 1957, p. 241-242; Teleman 1969, p. 22-36; Lødrup 1989, p. 83-86; Delsing 1993, p. 200-223).

Indefinite juxtapositional expressions have no phrase-internal structure showing subordination of one noun to the other. Phrase-external evidence can primarily be found in agreeing adjectival predicates (and, in Nynorsk and some dialects, perfect participles). It is hard to find good evidence from usage, since the combination of indefinite subjects and predicate complement constructions is infrequent. But the available evidence seems to point to a difference between primary and secondary measure nouns. Faarlund et al. (1997, p. 240, 769-70) note that in constructions with a primary measure noun, as exemplified in (30), the substance noun tends to trigger agreement; recall that this is the case for constructions with $\operatorname{masse}_{M N}$. In my judgement, agreement with the substance noun is the only option in this case, as for other primary measure nouns (of specific number, e.g. million; of indefinite number, e.g. rekke 'series, number'; of conventional measures, e.g. liter 'litre'; and of indefinite quantity, e.g. masse).

En mengde sardiner var råtne/?*råtten

a.M quantity(M) sardines be.PST rotten.PL/rotten.sG

'A lot of sardines were rotten'

In constructions with a secondary measure noun, as in (31), the measure noun tends to trigger agreement, according to Faarlund et al. According to my intuition, agreement with the substance noun is still the preferred option in (31), although agreement with the measure noun is more acceptable here than in (30).
(31) En boks sardiner var råtne/?råtten
a.M $\operatorname{tin}(\mathrm{M})$ sardines be.PST rotten.PL/rotten.sG
'A tin of sardines was rotten'

Hankamer and Mikkelsen (2008, p. 326) report that an attempt at collecting acceptability judgements of similar agreement options for Danish produced inconclusive results, which made them leave out such data; arguably, the vacillation may be regarded as evidence for variable structure. In light of their origin in genitival constructions, juxtapositional constructions appear partly to have undergone reanalysis, i.e. from (simplified) $[\mathrm{N}[\mathrm{N}]]$ to $[[\mathrm{N}] \mathrm{N}]$, and the reanalysed structure seems to be more strongly conventionalized for primary than for secondary measure nouns. Vacillation in agreement may then be accounted for as due to variation between the old and the new structure 
(see e.g. Delsing 1993). The development from $[\mathrm{N}[\mathrm{N}]]$ to $[[\mathrm{N}] \mathrm{N}]$ may be regarded as an indication of ongoing grammaticalization of the measure noun (see Section 8).

At first sight, prepositional expressions appear to have the (simplified) structure [N $[\mathrm{P}[\mathrm{N}]]]$. But such constructions, too, exhibit vacillating agreement properties, see (32) and (33).

(32) En mengde med sardiner var råtne/?*råtten

a.M quantity(M) with sardines be.PST rotten.PL/rotten.sG

'A lot of sardines were rotten'

(33) En boks med sardiner var råtne/råtten

a.M $\operatorname{tin}(M)$ with sardines be.PsT rotten.PL/rotten.sG

'A tin of sardines was rotten'

Recall from Section 3 that prepositional constructions with en masse med exhibit substance noun agreement. Agreement with the substance noun and vacillating agreement is found also in English, viz. in the agreement inflection of verbs in the present tense (plus was/were), e.g. as in (34)-(36) (cf. Langacker 1991, p. 88-89). Similar properties have been documented for Spanish prepositional measure noun constructions, e.g. (37), where the finite verb acercan agrees with personas rather than with aluvión (Delbecque and Verveckken 2014, p. 94-95).

(34) A lot of students were in the room

(35) A bunch of carrots was in the sink

(36) A bunch of students were in the room

(37) Un aluvión de personas se le acercan

a flood of persons REFL him approach

'A flood of persons approach him'

The adjectival or verbal agreement with the (apparently subordinate) substance noun in the apparent structure [N [P [N]]] is not straightforwardly accounted for. It might be regarded as semantic agreement, i.e. agreement that disregards the syntactic structure. Such an account could be extended to juxtapositional measure noun constructions: It would then not be necessary to assume that reanalysis had taken place there; the structure would be $[\mathrm{N}[\mathrm{N}]]$ regardless of agreement properties. This seems to be the view of Faarlund et al. (1997, p. 769-770).

However, several researchers on English and Spanish have argued that substance noun agreement is evidence that syntactic reanalysis has taken place even in prepositional structures (e.g. Delbecque and Verveckken 2014; Traugott and Trousdale 2013). That is, there has been a change from $[\mathrm{N}[\mathrm{P}[\mathrm{N}]]]$ to something like $[[\mathrm{N} \mathrm{P}] \mathrm{N}]$, e.g. $[[a$ 
bunch of $]$ students]. A different structure, [[N] [P N]], was proposed for Norwegian by Kinn (2001, p. 216-220), where the substance noun is the head and the preposition has become a head marker. Both analyses would account for external agreement properties, but the internal structure of the constructions is in both cases somewhat obscure.

The exact analyses of constructions headed by the substance noun will not be discussed in further detail here, since the focus is on structures where a former measure noun has become a quantifier (in terms of its word class, not just its function). What matters is that there does appear to be a change going on which switches head status from measure noun to substance noun, and which, in prepositional constructions, renders the status of the preposition unclear. This change is evidently a reanalysis whose semantic motivation is strong enough to override the quite transparent previous $[\mathrm{N}[\mathrm{P}$ [N]]] structure.

If the agreement of constituents external to the measure noun construction had been the only evidence for the restructuring, one might have argued that we are dealing with purely semantic agreement, and that the measure noun construction is always headed by the measure noun. However, in Norwegian there is also evidence from internal structure that there is more going on.

Not only adjectival predicate complements but also a nominal-internal plural determiner (definite article, demonstrative) may in some cases agree with a plural substance noun - 'across' the measure noun and (if present) a preposition. To demonstrate this, the Norwegian opposition between single and double definiteness must first be presented.

The term 'single definiteness' is used primarily about nominal constructions with a definite article followed by a quantifier and/or an adjective and an indefinite noun. This is mostly a conservative feature of written Bokmål, but is nevertheless common when followed by certain restrictive modifiers, especially restrictive relative clauses. An example is given in (38), where spørsmål is indefinite. The article de and spørsmål agree in number, but disagree in definiteness.

(38) de mange vanskelige spørsmål (som styret stiller) the.PL many.PL difficult.PL questions that the.board asks 'the many questions (that the board is asking)'

More commonly, the noun is in the definite form, yielding 'double definiteness'. This is exemplified in (39), where spørsmålene is definite. The article de and the noun spørsmålene agree both in number and in definiteness.

(39) de mange vanskelige spørsmålene (som styret stiller) the.PL many.PL difficult.PL the.questions that the.board asks 'the many questions (that the board is asking)' 
Examples (38) and (39) involve the quantifier mange 'many' modifying the substance noun with respect to its quantity. The distinction between single and double definiteness is also found in measure noun constructions. With two nouns involved, there are in principle two candidates for definiteness inflection in double definiteness and for the definite article to agree with.

Numeral nouns are the class of measure nouns apparently most prone to develop into quantifiers (see Section 8). They exhibit several constructional patterns and will serve to illustrate some essential points below. In single definiteness, the form of the nouns provides no clue to which one is the head, since both are indefinite, as shown for juxtapositional and prepositional measure noun constructions, respectively, in (40) and (41):

(40) alle de millioner mennesker som følger med på fotball all.PL the.PL millions human.beings that follow with on football 'all the millions of people that follow football'

(41) alle de millioner av mennesker som trenger hjelp all.PL the.PL millions of human.beings that need help 'all the millions of people that need help'

In double definiteness, the numeral noun may be definite and the substance noun indefinite, showing the headhood of the former, exemplified for juxtapositional and prepositional measure noun constructions, respectively, in (42) and (43):

(42) alle de millionene mennesker som ønsker å se Ham

all.pL the.PL the.millions human.beings that wish to see Him

'all the millions of people that wish to see Him'

(43) alle de millionene med mennesker som verken kan lese all.pL the.PL the.millions with human.beings that neither can read

eller skrive

nor write

'all the millions of people that can neither read nor write'

However, it is probably more common to have the numeral noun in the indefinite and the substance noun in the definite form, thus with the latter as head, as shown for juxtapositional and even for prepositional measure noun constructions in (44) and (45), respectively:

(44) alle de millioner menneskene som er preget etter all.PL the.PL millions the.human.beings that are marked after kommunismen

the.communism

'all the millions of people that are marked as a result of communism' 
(45) alle de millioner av menneskene som er på flukt fra all.PL the.PL millions of the.human.beings that are on flight from denne meningsløse krigen this meaningless the.war

'all the millions of people that are on the run from this meaningless war'

Constructions with numeral nouns allow an indefinite measure noun in the singular to appear between a plural article and a definite plural substance noun, as illustrated in (46) and (47):

(46) Det hersker stor spenning blant de ett tusen it rules great excitement among the.PL one.N thousand(N) bøndene $i$ Fjellregionen the.farmers in the.Mountain.Region

'There is much nervous anticipation among the farmers of the Mountain Region'

$$
\begin{aligned}
& \text {.. bør } i \text { alle fall to av de en million eggene } i \\
& \ldots \text { ought in all cases two of the.PL one.M million(M) eggs in } \\
& \text { denne rogna vokse opp } \\
& \text { this roe grow up } \\
& \text { 'should at least two of the one million eggs in this roe grow up' }
\end{aligned}
$$

These data confirm the rather vague indications from agreement data and indefinite measure noun constructions: The substance noun can be head, and headhood status may even override the prepositional marking.

The situation described for numeral nouns is far from common to all definite measure noun constructions. Most juxtapositional expressions show the measure noun to be superordinate, e.g. (48) in which the determiner de agrees with the measure noun literne). An expression like (49), with singular den agreeing with the substance noun vinen, is quite ill-formed. Prepositional expressions typically also have a structure indicating that the measure noun is the head, e.g. (50) with agreement between determiner and measure noun.

(48) de tre literne vin

the.PL three the.litres wine

'the three litres of wine'

(49) *den tre liter vinen

the.sG three litres the.wine

(50) de tre literne med vin

the.PL three the.litres with wine

'the three litres of wine' 
Apparently, double definiteness involving a substance noun requires that it and the article (or demonstrative) both be in the plural, and the measure noun must - if it is not a numeral noun - be in the abundance plural. Such expressions are not very common, and not everybody finds them quite acceptable. But it is my intuition - built on two decades of interest in abundance plurals - that they are becoming steadily more conventional; (51)-(55) provide illustration and give an impression of the kind of structure we are dealing with.

(51) Alle forgreiningene og de tusenvis av lungeblærene all the.branchings and the.PL thousand.ABU of the.alveoli renses og holdes åpne are.cleaned and are.held open

'All the branches and the thousands of alveoli are kept clean and open'

(52) men av alle de tonnevis av skytespillene på markedet er but of all.PL the.PL ton.ABU of the.shooting.games on the.market is det veldig lite som genuint interesserer meg it very little that genuinely interests me 'but among all the tons of shooting games on the market, there is very little that genuinely interests me'

(53) man må bruke traktor $p a ̊$ de milevis med grusveiene opp one must use tractor on the.PL mile.ABU with the.gravel.paths up til bondelandet

to the.farm.land

'one has to use a tractor on the miles of gravel paths up to the farm land'

(54) Det eneste problemet vil være desentraliseringen og alle de the only the.problem will be the.decentralization and all.PL the.PL drøssevis med nettverkene ton.ABU with the.networks

'The only problem will be decentralization and all the tons of networks'

(55) alle de massevis av produktene som inneholder billige raffinerte all.PL the.PL lot.ABU of the.products that contain cheap refined planteoljer plant.oils 'all the tons of products that contain cheap refined plant oils'

It seems quite clear in these examples that there is agreement between the definite plural article de and the definite plural substance noun, in spite of the intervening preposition. 
The examples in (51)-(55) all have double definiteness. Single definiteness is quite common, provided that there is a restrictive modifier, typically a relative clause, as in (56):

$\begin{array}{lllllll}V i & \text { har jo } & \text { kun besøkt et fätall av alle de } \\ \text { we have of.course } & \text { only visited a minority } & \text { of } & \text { all.PL the.PL }\end{array}$

hundrevis av campingplasser som finnes $i$ vårt langstrakte

hundred.ABU of camp.sites that exist in our long-stretched

land

country

'Of course, we've only visited a small minority of all the hundreds of camp sites that there are in our long-stretched country'

If there is no restrictive modifier (e.g. if the relative clause of (56) were left out), the result is stylistically clearly marked (conservative). This shows that it is the substance noun that partakes in the single vs. double definiteness distinction and is the head of the measure noun construction.

This rather long discussion has demonstrated that some measure nouns are subordinate to the substance noun of measure noun constructions. Importantly, as shown in Section 3, this holds for masse $_{M N}$.

\section{The larger picture: changes in measure noun constructions}

To gain a better understanding of the synchrony of measure noun constructions, it is useful to start with constructions that may be assumed to precede them diachronically. Discussing English measure noun constructions, Langacker (1991, p. 88) notes that some of the measure nouns (i.e. those here called secondary measure nouns) "have an interpretation in which they designate a physical spatially-continuous entity that either serves as the container for some portion of a mass (bucket, cup, [...]), or else is constituted of some such portion (bunch, pile, [...])". Norwegian measure noun constructions with med 'with' and $a v$ 'of' illustrate well the two conceptions of quantity described by Langacker. The use of med clearly evokes the conceptual relation between a container and its content, while the use of $a v$ evokes the relation between an object and its constitutive material (see Kinn 2001, p. 174-179). ${ }^{11}$ But neither of these conceptions are inherently quantifying. Nonquantifying uses illustrating this may be ei lommebok med 300 kroner 'a wallet with 300 kroner' and ei jakke av skinn 'a jacket (made) of leather'. In such cases, the syntactic structure is unambiguous (simplified: [N $[\mathrm{P}[\mathrm{N}]]])$. The relations denoted by the prepositions are understood literally, and the

11 Kinn (2001, p. 172-174) argues that the use of med in Norwegian has an additional relevant meaning that motivates an observed stronger preference for it in constructions of length and time, namely that of the relation between something accompanied and its accompaniment. 
nouns involved are not coextensive. ${ }^{12}$ The nominals may appropriately refer to wallets and jackets, but not to kroner and leather.

In measure nouns constructions, however, the nouns are coextensive, or as Kinn (2001, p. 5-6) says, they are weakly coreferential. In that work, it is regarded as a defining characteristic of measure noun constructions that the nominals refer to the same entity but categorize it in different ways. Thus, in (57), the 'lot' and the students are the same entity. In (58), the litres and the wine are the same. The measure noun refers to the mass by specifying its quantity ${ }^{13}$ while the substance noun provides qualitative information. The weakness of the coreferentiality lies in the difference in semantic substructures of the nouns. For instance, in (59), the collective of kilos and the collective of potatoes are the same whole entity, but the individual kilos and the individual potatoes are different entities. Verveckken (2015), dealing with Spanish, analyses measure noun constructions in a very similar way to Kinn (2001).

(57) en masse studenter

a.M $\operatorname{lot}(\mathrm{M})$ students

'a lot of students'

(58) to liter (med) vin

two litres (with) wine

'two litres of wine'

(59) fire kilo poteter

four kilos potatoes

'four kilos of potatoes'

The coreferentiality of both nouns is evident in Norwegian pairs like (60) and the closely synonymous (61). The prepositions med and $i$ are converses, the former relating a container to a content and the latter relating a content to a container. But here, the containment is metaphorical; container and content are the same.

(60) litervis med vin

litre.ABU with wine

'litres of wine'

(61) vin $i$ litervis

wine in litre.ABU

'litres of wine'

12 Assuming the jacket has a lining etc. in other materials.

13 Secondary measure nouns also contribute some qualitative information. 
The quantity of the substance is contributed more or less clearly by the measure noun. Secondary measure nouns do not specify an accurate quantity, but they tend to have a typical size associated with them, and this is how they come to be able to serve a quantifying function. Further, "these size implications can be foregrounded through pragmatic enrichment, to the detriment of the lexical meaning" (Brems 2011, p. 108-109). Some English measure nouns, like bunch, which have until recently been secondary measure nouns with a fairly clear qualitative meaning (e.g. a bunch of carrots), have developed a more general quantitative meaning, i.e. have become primary measure nouns (e.g. a bunch of students, a bunch of rubbish). The further this development goes, the more quantifier-like the measure noun becomes, and the more head-like the substance noun becomes.

The observed facts have explanatory power in relation to diachrony. The coextensiveness of the nouns explains why it matters little in terms of reference whether one or the other noun heads the referring expression. A reversal in head status between measure noun and substance noun corresponds to a subtle figure-ground reversal in the conceptual semantics of the measure noun construction - a metonymic shift. Given that the nouns are coextensive, the preposition in prepositional measure noun constructions (med or $a v$ in Norwegian, of in English) is of little referential importance. This explains why the clear syntactic hierarchy of such structures may be overridden in a semantically-based reanalysis, promoting the substance noun to head status and demoting the measure noun.

As the data and discussion above have shown, masse $_{M N}$ is among the demoted primary measure nouns in constructions involving the indefinite singular en masse and partly the abundance plural massevis.

\section{From primary measure noun to quantifier}

Constructions with primary measure nouns that have become subordinate to the substance noun in some cases continue into a development where the measure noun loses noun properties and instead acquires the modifier properties of a quantifier. One measure noun that has wholly undergone such a development is the predecessor of $t i$ 'ten' (now only a quantifier; compare modern Norwegian seksti '60' to Old Norse sex tigir [six tens]). The larger numeral nouns hundre 'hundred' and tusen 'thousand' exhibit some uses where they may be regarded as quantifiers, and so does par 'couple' (Kinn 2000). Masse is perhaps the youngest example.

The developments described above for Norwegian masse exhibit a number of characteristics of grammaticalization (see e.g. Lehmann 2015). When masse $_{N}$ develops the meaning variant of masse $_{M N}$, this is a case of desemanticization or bleaching. It is also a case of paradigmatization when the noun enters into the paradigm of measure nouns (which is rather large, but very much smaller than the paradigm of nouns in general). When en masse and masse come to be used as adverbial quantifiers and quantify 
over predicates in addition to nominal entities (as in (3) and (6) above), this is context expansion, which according to some theorists (e.g. Himmelmann 2004) is typical of grammaticalization. Paradigmatization continues with the development of a quantifier, since the class of quantifiers is rather limited compared to that of measure nouns. This downgrading change involves loss of nominal properties (i.e. decategorialization), namely gender, inflection for number and definiteness. But it also involves gain of the adjectival property of gradability (accepting degree modifiers). The developments have led to divergence (the expression masse belongs to different categories) and layering

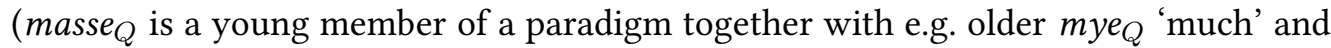
mange $_{Q}$ 'many').

Although the development from masse $_{M N}$ to masse $_{Q}$ may be regarded as a natural diachronic change, it also illustrates the piecemeal nature of language change. The development from a meaning of '(shapeless) matter, substance' to a purely quantitative meaning and further from noun to quantifier appears to have started not many generations after it was borrowed. The measure noun mengde 'lot, quantity' is similar in meaning and much older (derived from mang(e) 'many') but does not appear to be developing a quantifier variant. The different fates of masse and mengde may however not be accidental. Although both en masse and en mengde mean 'a lot', a difference comes out if we look at their use with adjectives. Mengde ${ }_{M N}$ is modified by adjectives of both large and small size (en stor mengde 'a large number/amount', en liten mengde 'a small number/amount'). Masse $_{M N}$ is infrequently used with adjectives of size (stor masse and liten masse typically refer to great and small mass in the physics meaning). Instead, it tends to be used with intensifying adjectives (en hel masse 'a whole lot', en helvetes masse 'a helluva lot'), which only go upwards. Thus, while the size meaning of mengde $_{M N}$ is manipulable in both directions, masse $_{M N}$ normally indicates only large amount. In that sense, the inherent meaning of masse $_{M N}$ makes it a better candidate for quantifier-hood than mengde $M N$.

\section{Conclusion}

The Norwegian quantifier masse 'a lot, lots, many, much' has developed from the measure noun masse 'matter, mass, large amount'. The development must probably have begun in the late 19th century, and the use of masse as a quantifier seems to have become conventionalized in informal language during the first few decades of the 20th century. In contemporary Norwegian, it is quite frequent, but it is still limited to informal language and hardly found in more formal text types such as laws and governmental reports. The development of a quantifier from a measure noun has been shown to be facilitated by the inherent variability of measure noun constructions, where semantically motivated reanalyses demote measure nouns from heads to quantifying modifiers. Such demotion may be regarded as a first step towards grammaticalization from noun to quantifier. 


\section{Acknowledgements}

I wish to thank the two anonymous referees, whose suggestions have helped me to improve this text.

\section{Appendix: Sources of examples}

[1-6] LBK, fiction

[7-8] Author's examples.

[9] Norske Intelligenssedler, 1773, from nb.no

[10] Den Norske Rigstidende, 1819, from nb.no

[11] LBK, newspapers

[12] LBK, textbooks

[13] LBK, newspapers

[14] LBK, journals

[15-16] Norsk Aviskorpus (NAK), avis.uib.no

[17] George Manville Fenn, Et dobbelt Problem (translated from English, anonymous translator), from nb.no

[18] George de Horne Vaizey, Huset ved veien (translated from English by Ingeborg von der Lippe Konow), from nb.no

[19] Adam Hiorth, "Barnehjælpsdag" in Det Norske studentersamfunds viser og sange gjennem hundrede aar: 1813-1913, from nb.no

[20] Julli Wiborg, Ragna, from nb.no

[21] George de Horne Vaizey, Darsie (translated from English by Ingeborg von der Lippe Konow), from nb.no. Found by one of the anonymous reviewers.

[22] John Bergh, Den vidunderlige globus (translated from Swedish by G. Emil Thomassen), from nb.no

[23] Norsk riksmålsordbok (1937-1957), vol. 2, part 1

[24] www.annicaolsson.se

[25] esmark.dk

[26] org.ntnu.no

[27] tormodsgate8.weebly.com

[28] TxtC

[29] LBK, fiction

[30-33] Faarlund et al. (1997, p. 240). Author's grammaticality judgements.

[34-36] Langacker (1991).

[37] Delbecque and Verveckken (2014).

[38-39] Author's examples.

[40] shop.flammeforlag.no

[41] www.adventist.no

[42] www.verdidebatt.no

[43] paeliassen.no

[44] unitedforumet.no

[45] nettavisen.no

[46] www.retten.no

[47] fiskeribladet.no

[48-50] Author's examples.

[51] LBK

[52] www.gamereactor.no

[53] vgd.no

[54] www.diskusjon.no 
[55] www.helhetligliv.no

[56] bobilverden.no

[57-61] Author's examples.

\section{References}

Bokmålsordboka (2005). 3rd ed. Oslo: Kunnskapsforlaget.

Brems, Lieselotte (2011). Layering of Size and Type Noun Constructions in English. Berlin: De Gruyter.

Clerck, Bernard De and Lieselotte Brems (2015). "Size nouns matter: a closer look at mass(es) of and extended uses of SNs”. In: Language Sciences 53, pp. 160-176.

Delbecque, Nicole and Katrien Dora Verveckken (2014). "Conceptually driven analogy in the grammaticalization of Spanish binominal quantifiers”. In: Linguistics 52, pp. 637-684.

Delsing, Lars-Olof (1993). The Internal Structure of Noun Phrases in the Scandinavian Languages. Lund: Dept. of Scandinavian Languages, University of Lund.

Diderichsen, Paul (1957). Elementær Dansk Grammatik. 3rd ed. Copenhagen: Gyldendal.

Enger, Hans-Olav and Philipp Conzett (2016). "Morfologi”. In: Norsk språkhistorie. Ed. by Helge Sandøy. Vol. 1: Mønster. Universitetsforlaget, pp. 213-315.

Faarlund, Jan Terje, Svein Lie, and Kjell Ivar Vannebo (1997). Norsk referansegrammatikk. Oslo: Universitetsforlaget.

Hankamer, Jorge and Lise Mikkelsen (2008). "Definiteness marking and the structure of Danish pseudopartitives". In: Journal of Linguistics 44, pp. 317-346.

Himmelmann, Nikolaus P. (2004). "Lexicalization and grammaticalization: Opposite or orthogonal?” In: What Makes Grammaticalization: A Look from its Components and its Fringes. Ed. by Walter Bisang, Nikolaus P. Himmelmann, and Björn Wiemer. Berlin: Mouton de Gruyter, pp. 21-42.

Kinn, Torodd (2000). "Eit par tankar om par". In: Menneske, språk og fellesskap. Festskrift til Kirsti Koch Christensen på 60-årsdagen 1. desember 2000. Ed. by Øivin Andersen, Kjersti Fløttum, and Torodd Kinn. Oslo: Novus, pp. 135-140.

- (2001). "Pseudopartitives in Norwegian". PhD thesis. University of Bergen.

- (2004). "Stribevis af eksperter, drøssevis av sjansar, hinkvis med kaffe: An emerging plural of abundance in the Scandinavian languages". In: Proceedings of the 20th Scandinavian Conference of Linguistics, Helsinki, January 7-9, 2004. Ed. by Fred Karlsson. Helsinki: Dept. of General Linguistics, University of Helsinki.

- (2005). "Ord på -vis i moderne norsk: samansetningar, avleiingar - og bøyingsformer?” In: Maal og Minne 2005, pp. 45-78.

Koptjevskaja-Tamm, Maria (2001). “"A piece of the cake” and "a cup of tea”: Partitive and pseudo-partitive nominal constructions in the Circum-Baltic languages”. In: Circum-Baltic Languages. Ed. by Östen Dahl and Maria Koptjevskaja-Tamm. Vol. 2: Grammar and Typology. Amsterdam: Benjamins, pp. 523-568. 
Langacker, Ronald W. (1991). Foundations of Cognitive Grammar. Vol. 2: Descriptive Application. Stanford, CA: Stanford University Press.

Lehmann, Christian (2015). Thoughts on Grammaticalization. 3rd ed. Berlin: Language Science Press.

Lødrup, Helge (1989). Norske hypotagmer. Oslo: Novus.

Norsk riksmålsordbok (1937-1957). Oslo: Aschehoug.

Teleman, Ulf (1969). Definita och indefinita attribut i nusvenskan. Lund: Studentlitteratur.

Traugott, Elizabeth Closs and Graeme Trousdale (2013). Constructionalization and Constructional Changes. Oxford: Oxford University Press.

Verveckken, Katrien Dora (2015). Binominal Quantifiers in Spanish. Berlin: De Gruyter. 